\title{
Application of PjBL with brain-based STEAM approach to improve learning achievement of students
}

\author{
Nur Lailatul Badriyah *, Anik Anekawati, Lutfiana Fazat Azizah \\ Department of Science Education, Universitas Wiraraja. \\ Jalan Raya Sumenep-Pamekasan KM. 05 Kabupaten Sumenep, Jawa Timur 69451, Indonesia. \\ * Corresponding Author. E-mail: nurlailatulb02@gmail.com
}

Received: 29 January 2020; Revised: 7 July 2020; Accepted: 10 July 2020

\begin{abstract}
The purpose of this study is to determine differences in student's learning achievement consisting of learning outcomes and science process skills. This research was conducted in a special school for girls and used two experimental classes, namely experimental class- 1 and experimental- 2 class. The experimental class- 1 is the class applied by PjBL with a brain-based STEAM approach, while the experimental class- 2 is a class that uses PjBL with the STEAM approach without brain-based. This research is a quasi-experimental study with a nonequivalent pre-test-post-test control group design. The data analysis technique used is the Ttest. The brain-based learning activities applied in this study are listening to music, drinking water, doing a brain gym, working on crossword puzzles, and group determination based on the dominance of students' brains. The results showed that the average value of the $\mathrm{N}$-Gain score of student learning outcomes in the experimental class- 1 was 80,72 . Student learning outcomes experimental class- 2 is 73,12 . In science process skills, the experimental class-1 students had an average N-Gain score of 72,50, while the experimental-2 class was 60,88 . The conclusion is the experimental class 1 students have higher learning achievement than students in the experimental class 2.
\end{abstract}

Keywords: Brain-based learning, Learning outcomes, PjBL, Science process skills, STEAM

How to Cite: Badriyah, N., Anekawati, A., \& Azizah, L. (2020). Application of PjBL with brain-based STEAM approach to improve learning achievement of students. Jurnal Inovasi Pendidikan IPA, 6(1), 88-100. doi:https://doi.org/10.21831/jipi.v6i1.29884

\section{INTRODUCTION}

Program for International Student Assessment or called PISA is an ongoing program that offers information on educational policies and practices and helps monitor the acquisition of students' knowledge and skills in various countries (Organisation for Economic Co-Operation and Development, 2015). The PISA grading system is conducted every three years for students aged 15 years who are randomly selected (Fernandez-Cano, 2016). The competencies tested in PISA are reading, mathematics, and science competencies (She et al., 2018). Seventy-two countries participated in the PISA assessment system in 2015 (Organisation for Economic Co-Operation and Development, 2015). Since the implementation of PISA in 2000, PISA test results have gradually become the global standard for the quality of education in a country (Sjøberg, 2015). The results of the PISA test in 2001 showed that several developed countries had poor outcomes, such as Germany (Gorur, 2014) and Norway (Sjøberg, 2015).

According to the Ministry of Education and Culture in Indonesia, Indonesia's participation in PISA in 2000, shows that the achievements of children in Indonesia are still below other developing countries (Peraturan Menteri Pendidikan Dan Kebudayaan Nomor 68 Tahun 2013 Tentang Kerangka Dasar Dan Struktur Kurikulum Sekolah Menengah Pertama/Madrasah Tsanawiyah, 2013). The results released by PISA show that Indonesia is yet ranked 10th lowest (Biro Komunikasi dan Layanan Masyarakat Kementerian Pendidikan dan Kebudayaan, 2016). Therefore, the Indonesian Ministry of Education and Culture evaluates the results of the PISA to formulate a new curriculum (Paparan Wakil Menteri Pendidikan Pendidikan dan Kebudayaan Republik Indonesia, 2014). The curriculum is called the 2013 curriculum and is implemented starting in the 2013/2014 school year (Peraturan Menteri Pendidikan Dan Kebudayaan Nomor 68 Tahun 2013 Tentang Kerangka Dasar Dan Struktur Kurikulum Sekolah Menengah Pertama/Madrasah Tsanawiyah, 2013).

In addition to the PISA test results, the reasons for the development of the 2013 Curriculum in Indonesia include advances in science and technology, improving the creative and cultural industries, a 
convergence of science and technology, and transformation in education (Paparan Wakil Menteri Pendidikan Pendidikan dan Kebudayaan Republik Indonesia, 2014). The ability to communicate, the ability to live in a global society, readiness to work, and have intelligence following their respective fields are things to consider in the application of the 2013 Curriculum (Peraturan Menteri Pendidikan Dan Kebudayaan Nomor 68 Tahun 2013 Tentang Kerangka Dasar Dan Struktur Kurikulum Sekolah Menengah Pertama/Madrasah Tsanawiyah, 2013). The form of learning in the 2013 Curriculum must also prepare students to enter the workforce, as consideration for the development of the 2013 Curriculum is to have the readiness to work (Paparan Wakil Menteri Pendidikan Pendidikan dan Kebudayaan Republik Indonesia, 2014).

The world of work in the fields of technology, communication, and informatics is expected to continue to increase for the next ten years (Frey \& Osborne, 2017). Kor and Zakaria (2019) added that there is about 75 percent of new jobs available in these fields in Western Australia. To formwork readiness for the younger generation, it is necessary to improve the system in education (Centre for the New Economy and Society, 2018). Therefore, we need an education system that is suitable to be applied in this era of technology and information, one of which is learning STEM (Science, Technology, Engineering, and Mathematics) (Roberts, 2012). Recent research in the United States shows that skills in the STEM field also provide higher employment expectations than other areas (Casey, 2012; Hudha et al., 2019). Therefore several countries agree to the application of STEM learning, including the Japan (Takebayashi \& Kumano, 2018) United States, Korea, Singapore, the United Kingdom (Jho et al., 2016).

But STEM learning alone is not enough to do. (Creative Industries Federation, 2015) States that learning also requires the development and maintenance of innovation through the integration of elements of art. The inclusion of art elements in education can improve student inquiry skills, problemsolving skills, and creative thinking (Psycharis, 2018), make learning more exciting, increase the creativity of students and develop knowledge and social abilities (H. Kim \& Chae, 2016). Besides, the application of STEM learning can increase the level of student productivity (Kaleci \& Korkmaz, 2018). So there was a shift from STEM to STEAM (Psycharis, 2018). STEAM learning is learning that integrates elements in STEM and the addition of art elements (Watthananon, 2018). The integration of art elements in STEAM shows that education is interdisciplinary learning (Henriksen, 2017), which is considered as an accommodation for students to change in various fields of knowledge (M. K. Kim et al., 2019). Interdisciplinary learning not only provides learning experiences in different disciplines but also provides expertise in producing (Holley, 2017).

Similar to STEAM, the project-based learning model ( $\mathrm{PjBL}$ ) also involves students in producing a product and can improve student productivity capabilities (Spoelstra et al., 2014). This is because PjBL is a learning model that provides learning experiences for students in the form of designing and working on projects to produce a product (Larmer \& Mergendoller, 2015). The purpose of implementing PjBL is to hone students' knowledge and skills through project work activities following the material and competencies students have (Sani, 2014). Similarly, as stated by (Zubaidah et al., 2017) that PjBL is designed to create an appropriate learning environment for students to solve problems in daily life. So students are able to deal with a variety of situations (Susetyarini et al., 2019). According to Sani (2014), the PjBL stage consists of 6 images entered in the Figure 1.

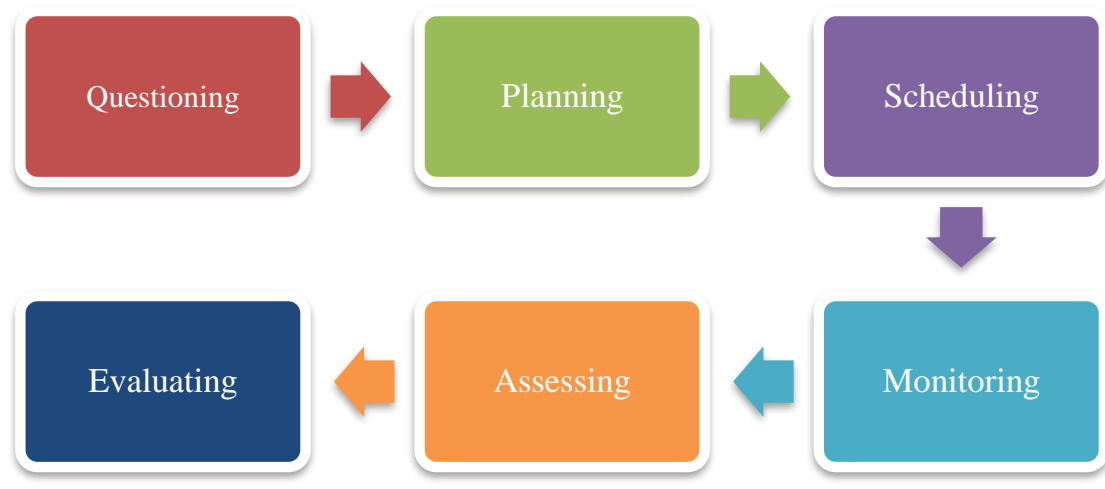

Figure 1. Syntax of PjBL (Sani, 2014)

To implementing PjBL in learning, it must begin with asking questions by the teacher to make students are motivated to investigate. Then proceed with the project design activities and determine the 
schedule. Next is the action of monitoring the progress of projects that have been done by students. Then enter the stage of product assessment and evaluation of student experience in making products (Darmadi, 2017). Figure 2 is a picture of the experience cone, according to Edgar Dale.

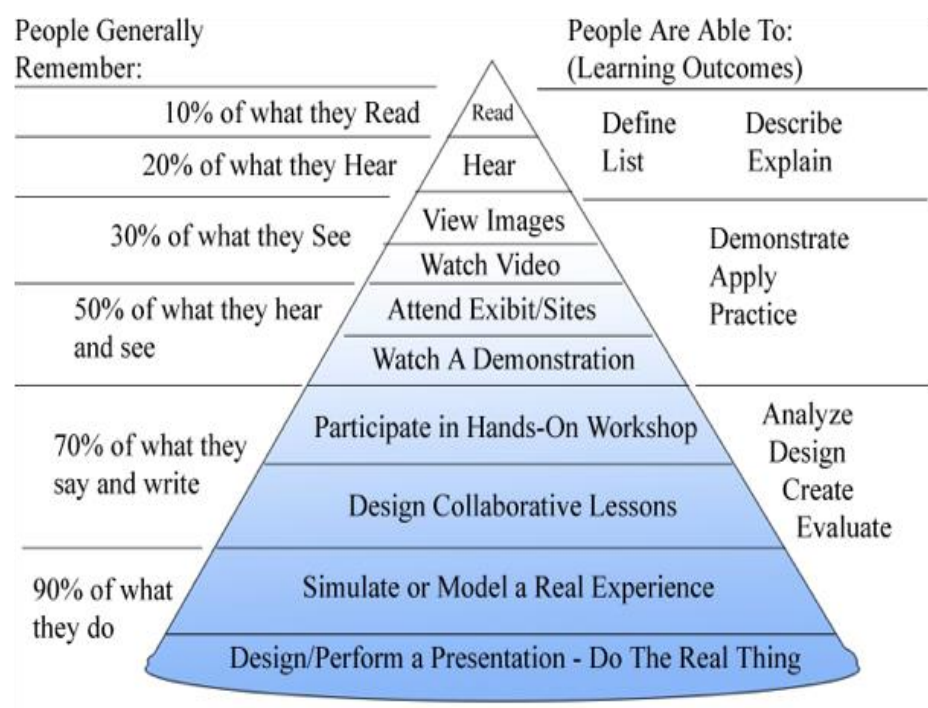

Figure 2. Edgar Dale's cone experience (Sani, 2015)

Based on Edgar Dale's cone experience, through the activities of designing and working on projects in PjBL, resulting in students having high memory (Jackson, 2016). Besides, student experience can train students to think and apply concepts so that they meet every aspect of the science process skills (Siwa et al., 2013). Therefore Ozer and Ozkan (2012) states that the application of PjBL is effectively applied to improve students' science process skills. STEAM learning is very suitable if it is integrated with PjBL because it integrates every element in STEAM (Hadinugrahaningsih et al., 2017). Through the integration of STEAM in PjBL, there will be many ways to shape learning experiences for students, to make learning activities more fun (Miller, 2014).

The principle of learning that is fun, according to Hannah (2013) is learning that pays attention to the condition of students to learn so that they can develop their abilities. This can be obtained through brain-based learning, namely learning that considers the condition of students' brains to keep working optimally (Jensen, 2011). The principle of brain-based learning is learning that can balance students' right and left hemispheres (Quiles-Moukaddem \& Hernandez, 2011).

The ability of students who are dominant in the left hemisphere includes the ability in language and logic, while the abilities in dominant students in the right brain are the ability of creativity and intuition (Corballis, 2014). Zulkaida et al. (2005) added that the ability of students who are dominant right brain is the ability in music, writing, reading, art, and imagination. For students who are dominant left brain will have the ability to conclude and analyze. In addition, Jensen (2011); Purwaningsih et al. (2015); and Sumardi (2014) also argue about the characteristics of students who are dominant right brain and left brain dominant as summarized in the Table 1.

Table 1. Differences in Characteristics of The Right Brain and Left Brain

\begin{tabular}{ll}
\hline \multicolumn{1}{c}{ Characteristics of the left hemisphere } & \multicolumn{1}{c}{ Characteristics of the right hemisphere } \\
\hline Liked calculation learning activities & Liked the activity of learning the art \\
Tend to be active with the right side of the body & Tend to be active with the left side of the body \\
Verbal communication & Nonverbal communication \\
Like words, symbols, tables, and letters & Liked graphics, pictures, and charts \\
Learn from part to whole & Learn from the whole to parts \\
Gather factual information & Gather information about relationships \\
Liked sequential things & Like random things \\
\hline
\end{tabular}

(Jensen, 2011; Purwaningsih et al., 2015; Sumardi, 2014)

Implementation of brain-based learning can be done by dividing the dominance of students' brain dominance groups heterogeneously. It is intended that interaction between students can be increased so 
that it is following the principle that the brain is a social brain (Frith, 2007). Interaction and communication in groups are needed to achieve success in learning (Iksan et al., 2012).

The characteristic of brain-based learning is applying the rest period in learning (Jensen, 2011). Activities that can be carried out when implementing a rest period are (1) brain gym (Ramakrishnan \& Annakodi, 2013); (2) downtime; (3) reflection; (4) relaxation; (5) asking students to drink water (Jensen, 2011); (6) listening to music or videos for students who are left-brain dominant; (7) playing games that can hone the minds of students who are dominant right brain, for example answering questions of crossword puzzles (Purwaningsih et al., 2015). Matching the answers with the number of boxes available in the crossword puzzle can give students curiosity and will be motivated to answer the question (Sazati, 2015). Thus, practice answering questions about crossword puzzles can improve students' thinking abilities (Laksmi et al., 2014). The activity of answering questions about crossword puzzles can be used by the teacher to hone the students' left brain (Purwaningsih et al., 2015).

The activity of listening to music in learning causes students to be relaxed (Ellis \& Thayer, 2010) so that they are better prepared to accept further learning (Pfeiffer \& Sabe, 2015). The activity of asking students to drink water is intended to meet the needs of students' brains (National Service Center for Environmental Publications (NSCEP), 2013) so that they can meet the needs of students' bodily fluids to keep concentrating on learning (Buanasita et al., 2015). The application of the brain gym aims to minimize the saturation of students (Sesmiarni, 2014). Besides, the role of the brain gym can expedite blood flow, trade muscle (Ramakrishnan \& Annakodi, 2013), and increase learning concentration (Watson \& Kelso, 2014). Movement in the brain gym can be used as an exercise in balancing the right brain and left brain of students (Abduh \& Tahar, 2018).

The science learning process tends to be logistic (Amriyah, 2018). Similarly, the mindset of boys who tend to be logical (Amin, 2018). This is supported by the results of PISA in 2012, which showed that boys had better STEM achievements than girls (Organization for Economic Co-operation and Development, 2014). However, research conducted by Ismail et al. (2016) is the opposite of (Organization for Economic Co-operation and Development, 2014), where achievements in the STEM field of girls are better than boys. It is also different from research by (Afriana et al., 2016), which shows boys have the same STEM achievements as girls. So that gender differences cannot be generalized in terms of increasing student achievement in the STEM field. This requires further research on student achievement in the integrated STEAM field. Therefore, this research will be conducted in special schools for women through brain-based STEAM learning and STEAM learning without brain-based.

\section{METHOD}

This research is a study that was applied to a special school for girls, namely SMP Plus Miftahul Ulum. This research was conducted in the even semester of the 2018/2019 school year. The type of this study is a quasi-experimental research design, which uses experiment- 1 class and experimental- 2 class. The population in this study were 88 students of class VIII, consisting of three classes, namely class VIII-A, VIII-B, and class VIII-C. The amount of students in each class is 30, 27, and 31, respectively. Before the sample selection is made, homogeneity tests will be conducted first to ensure students in the experimental class- 1 and the experimental class- 2 have the same variant or are called homogeneous. Randomization will be carried out if all samples show homogeneous results.

Student learning groups in the experimental class- 1 are distinguished by upper-lower and rightleft class categories, whereas the experimental class-2 is based on the upper-lower class only. The experimental class-1 is a class implemented by the PjBL with a brain-based STEAM approach, while the experimental class- 2 is a class that will be applied by a PjBL with a brain-based STEAM approach. Learning material that will be applied in the experimental class- 1 and experimental class- 2 is about sound waves in KD 3.11. Analyzing the concepts of vibration, waves, and sounds in everyday life, including human hearing systems and sonar systems in animals. The forms of brain-based learning activities for students in the experimental class-1 are as follows: doing a brain gym, group formation based on student brain dominance, drink water, listening to music for left-brain dominant students, and working on crossword questions for students who are right-brain dominant.

Learning achievement will be processed through learning outcomes and science process skills tests of students. Data collection instruments that will be used are tests of the dominance of students' brains, tests of learning outcomes, and tests of science process skills. The brain dominance test of 
students' is done before the application of learning, which aims as a guideline for group formation in students in the experimental class-1. The form of students' brain dominance tests is in the form of multiple-choice questions with a total of 20 items.

The instruments in this study were in terms of learning outcomes, questions about science process skills, brain dominance tests, learning plans, and inquiry instructions. All instruments will be validated by two experts each. As for the test results of learning and science process skills tests, will be tested to other schools and then tested the difficulty, validity, and reliability. The implementation of learning will be observed by two observers. The aim is to observe the suitability of the learning plan and its application. These two observers will observe through learning videos that have been previously recorded in the experimental class- 1 and the experimental-class 2.

Learning outcomes and science process skills tests in the form of essay questions that are carried out twice, namely pre-test and post-test. The pre-test is done before treatment, while the post-test is done after treatment. The cognitive level used as a reference for making learning outcomes test is $\mathrm{C} 4$ (Analyzing). Whereas the matter of science process skills measured is only basic science process skills in aspects of observing, concluding, interpreting, applying concepts, and communicating.

Improved student learning outcomes and science process skills between before and after treatment are obtained through the calculation of the $\mathrm{N}$-Gain score. The data analysis technique that will be used is a two-sample free T-test if the N-Gain score data of learning outcomes and science process skills of students are normally distributed. However, if it is not normally distributed, the Mann-Whitney test will be used.

\section{RESULTS AND DISCUSSIONS}

\section{Instrument Test Results}

The following is a summary table of results of instrument validation testing by experts.

Table 2. Expert Validation Test Results

\begin{tabular}{lccc}
\hline \multirow{2}{*}{ Instrument Type } & \multirow{2}{*}{ Expert } & \multicolumn{2}{c}{ Percentage of Eligibility } \\
\cline { 3 - 4 } & 1 & $92 \%$ & II \\
\hline Brain Dominance Test & 2 & $92 \%$ & - \\
& 1 & $92 \%$ & - \\
Lesson Plan in the first experimental class & 2 & $92 \%$ & - \\
\multirow{2}{*}{ Lesson Plan in the second experimental class } & 1 & $92 \%$ & $98 \%$ \\
& 2 & $92 \%$ & - \\
Investigation Instructions & 1 & $87,5 \%$ & $100 \%$ \\
Learning Outcomes Test & 2 & $91,6 \%$ & - \\
& 1 & $75 \%$ & $95 \%$ \\
Science Process Skills Test & 2 & $77,5 \%$ & $90 \%$ \\
& 1 & $75 \%$ & $95 \%$ \\
& 2 & $75 \%$ & $92,5 \%$ \\
\hline
\end{tabular}

The Table 2 shows that all instruments have an eligibility percentage above $75 \%$. This shows that the instrument used is suitable for use in a study.

Learning outcomes and science process skills tests that have been tested at other schools, then the difficulty, validity, and reliability are measured. The following are the results of the difficulty test about the learning outcomes and science process skills.

Table 3. Difficulty Test Results

\begin{tabular}{cccc}
\hline Instrument & Interpretation & No. item & Percentage \\
\hline Learning Outcomes Test & Medium & $1,2,3,4$, and 6 & $83 \%$ \\
& Easy & 5 & $17 \%$ \\
Science Process Skills Test & Medium & $1,2,3,4$, and 5 & $100 \%$ \\
\hline
\end{tabular}

Table 3 shows that learning outcomes have medium and easy interpretation, while science process skills questions have medium interpretation. The results of the validity test on the instrument are shown in Table 4. 
Jurnal Inovasi Pendidikan IPA, 6 (1), 2020 - 93

Nur Lailatul Badriyah, Anik Anekawati, Lutfiana Fazat Azizah

Table 4. Summary of Validity Test Results

\begin{tabular}{ccccc}
\hline Instrument & Information & Total & No. item & Percentage \\
\hline Learning Outcomes Test & Valid & 3 & 1,2 , and 6 & $50 \%$ \\
& Invalid & 3 & 3,4 , and 5 & $50 \%$ \\
Science Process Skills Test & Valid & 3 & 1,4 , and 5 & $60 \%$ \\
& Invalid & 2 & 2 and 3 & $40 \%$ \\
\hline
\end{tabular}

Table 4 shows that there are three valid and invalid questions each in the learning outcome questions. In the matter of science process skills have three valid categories and two questions with invalid categories. The results of a reliability test on the instrument trials are shown in the Table 5.

Table 5. Summary of Reliability Test Results

\begin{tabular}{lcc}
\hline \multicolumn{1}{c}{ Instrument } & Cronbach Alpha Value & Information \\
\hline Learning Outcomes Test & 0,724 & Reliable \\
Science Process Skills Test & 0,737 & Reliable \\
\hline
\end{tabular}

The Table 5 shows that the results of learning and science process skills have a level of reliability with a reliable category.

\section{Learning Implementation Results}

The results of the implementation of learning carried out to measure the suitability of the learning plan with learning activities. Figure 3 is a picture of the percentage agreement between Observer 1 and Observer 2 in the experimental class- 1 and the experimental-class 2.

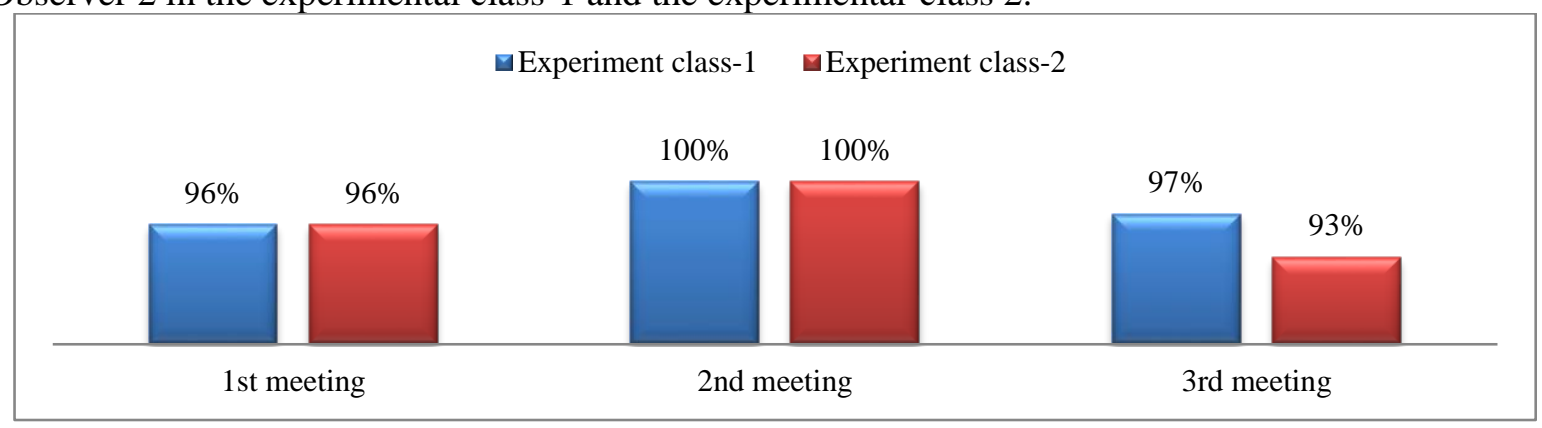

Figure 3. Percentage of Observers' Agreements in Experimental Class 1 and 2

The Figure 3 shows that the percentage of observer agreement in the experimental class -1 and experiment- 2 at 1 st meeting was $96 \%$, the percentage of observer agreement in the experimental class1 and experiment- 2 at 2 nd meeting was $100 \%$, the percentage of observer agreement in the experimental class- 1 at 3 rd meeting was $97 \%$ and the percentage of observer agreements in the experimental class- 2 3rd meeting was $93 \%$.

\section{Homogeneity Test Results}

A homogeneity test was performed using the results of students' daily tests. Here is a table of homogeneity test results (Table 6).

Table 6. Homogeneity Test Results

\begin{tabular}{lcc}
\hline \multicolumn{1}{c}{ Class } & Significance & Information \\
\hline Class VIII-A and VIII-B & 0,233 & Homogen \\
Class VIII-B and VIII-C & 0,687 & Homogen \\
Class VIII-A and VIII-C & 0,439 & Homogen \\
\hline
\end{tabular}

The Table 6 shows that all classes have the same or homogeneous variants. Therefore randomization was carried out to determine the experimental class- 1 and the experimental class- 2 . The randomization results are class VIII-B as experimental class-1, while class VIII-C as an experimental class-2.

\section{Brain Dominance Test Results}

The brain dominance test is applied in the experimental class- 1 for group formation according to the dominance of the students' brains. The following is a comparison picture of the brain dominance of students in the experimental class-1 (Figure 4). 


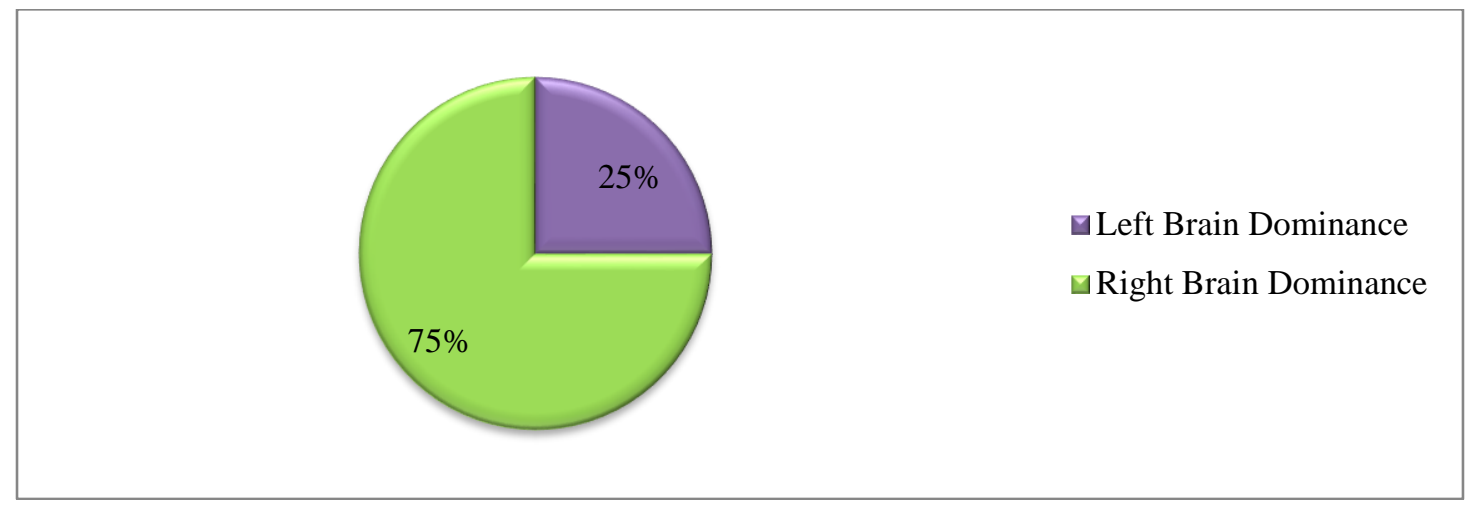

Figure 4. Comparison of Student Brain Dominance in the Experimental Class-1

Based on the Figure 4, it can be concluded that the majority of students in the experimental class1 have right-brain dominance with a percentage of $75 \%$, while the dominant brain is $25 \%$. This shows that students in the experimental-1 class tend to have the ability to play music, imagine, and draw. It's the same as what is stated by Jensen (2011) students who are dominant right brain tend to have the ability to play music, images, and draw.

\section{Learning Outcomes Data}

Student learning outcomes data of experimental class- 1 and experimental class- 2 are summarized in the Table 7.

Table 7. Learning Outcomes Data of Student

\begin{tabular}{ccccc}
\hline Class & Test form & Average value & Average N-Gain score & N-Gain score criteria \\
\hline Experiment Class-1 & Pre-test & 6,48 & \multirow{2}{*}{ High } \\
& Post-test & 81,85 & & High \\
\hline
\end{tabular}

Table 7 shows that the N-Gain score of the experimental class- 1 is 80,72 higher than the N-Gain score of the experimental class-2, which is 73,12 . Criteria for the N-Gain score in the experimental class1 and experimental class- 2 are high.

\section{Science Process Skills Data}

Data on the science process skills of the experimental class- 1 and experimental class- 2 students are summarized in the table below.

Table 8. Science Process Skills Data of Student

\begin{tabular}{ccccc}
\hline Class & Test form & Average value & Average N-Gain score & N-Gain score criteria \\
\hline Experiment Class-1 & Pre-test & 10,37 & 72,50 & High \\
& Post-test & 75,19 & & \multirow{2}{*}{ Medium } \\
\hline
\end{tabular}

The Table 8 shows that the N-Gain score of the experimental class- 1 is 72,50 better than the $\mathrm{N}$ Gain score of the experimental class-2 class, which is 60,88. Criteria for N-Gain score in the experimental class- 1 is high while in the experimental class- 2 is medium.

\section{Normality Test Results}

Table 9 below summarizes the results of normality tests.

Table 9. Summary of Normality Tests Results

\begin{tabular}{lcccl}
\hline \multicolumn{1}{c}{ Data type } & Class & Significance & Information & \multicolumn{1}{c}{ Statistic test } \\
\hline Learning Outcomes Data & Experiment-1 & 0,200 & Normal distribution & T-test for two free \\
& Experiment-2 & 0,062 & Normal distribution & samples \\
Science Process Skill & Experiment-1 & 0,000 & Not Normal distribution & Mann-Whitney Test \\
Data & Experiment-2 & 0,200 & Not Normal distribution & \\
\hline
\end{tabular}


Table 9 shows that learning outcomes in the experimental class- 1 and the experimental class- 2 have normally distributed data. So the decision of the statistical test uses the T-test for two free samples. Another case is the science process skills of students in the experiment class- 1 that is not normally distributed. But in the experimental class-2, science process skills data have normally distributed datastatistical decision tests for $\mathrm{N}-$ Gain process skill scores using the Mann-Whitney test.

\section{Statistical Test Results}

A summary of the statistical test results is shown in Table 10.

Table 10. Summary of Statistical Tests Results

\begin{tabular}{lcccc}
\hline \multicolumn{1}{c}{ Data type } & Statistic test & Significance & Alpha & Decision \\
\hline Learning Outcomes Data & T-test for two free samples & 0,034 & 0,05 & There is a difference \\
Science Process Skill Data & Mann-Whitney Test & 0,001 & 0,05 & There is a difference \\
\hline
\end{tabular}

The Table 10 shows that there are differences in students' learning outcomes and science process skills between the experimental class- 1 and the experimental- 2 class.

The learning equation applied to experiment class-1, and experiment class- 2 is the project-based learning model (PjBL) with the STEAM approach. The success of the application of learning is evidenced by the post-test average value, which is higher than the average pre-test value (Table 7). The implementation of $\mathrm{PjBL}$ in the experimental class- 1 and the experimental- 2 class provides active learning experiences for students in the form of designing and working on projects carried out in collaboration and making product presentations, as the opinions expressed (Larmer \& Mergendoller, 2015) that the application of PjBL causes students to be involved in the process of planning and working on projects so they can produce a product. This is consistent with the statement Jackson (2016) that through learning experiences such as resulting in students having high memory. The integration of art elements in this research is in the form of project design activities. Through this activity, students are very interested in participating in learning, which is shown by the enthusiasm of students in asking questions and expressing opinions. This is consistent with the idea H. Kim and Chae (2016) that activities in the aspect of art make students more interested in learning.

Increasing the average value of the $\mathrm{N}$-Gain score of student learning outcomes in experimental class- 1 and experimental class- 2 is not the same. The average value of the $\mathrm{N}$-Gain score of student learning outcomes in the experimental class- 1 is higher than in the experimental class- 2 . This is caused by differences in learning that is applied in each class. The difference in learning that is applied in the experimental class- 1 and the experimental-2 class is brain-based learning.

Students who are left-brain dominant are treated in the form of listening to music using earphones. Based on researchers' observations, students are more enthusiastic about learning after being given treatment in the form of listening to music. This is consistent with the opinion Ellis and Thayer (2010) that music in learning can cause students to be relaxed so that they are better prepared to participate in further learning (Pfeiffer \& Sabe, 2015). Right-brain dominant students are given special treatment in the form of doing crossword puzzles. The aim is to sharpen the left side of the student's brain as an opinion (Purwaningsih et al., 2015) that through crossword puzzles, the teacher can sharpen the left brain of the student. Based on researchers' observations, students are very serious about working on crossword puzzles. This is following the opinion (Sazati, 2015) that is working on the problem of crosswords, and students will be motivated to continue thinking through matching the answers with the box provided. So that students' thinking skills can be improved (Laksmi et al., 2014).

Students in the experimental class-1 also received drinking water treatment. This is intended to prevent dehydration in students, as the opinion (National Service Center for Environmental Publications (NSCEP), 2013) that teachers must take care of the needs of students' brains, one of which is to prevent lack of fluids in the student body. Based on the researchers' observations, the experimental class-1 students were more active than the students in the experimental-2 class. In addition, some students in the experimental class- 2 are sleepy. This is because students in the experimental class- 1 get treatment in the form of drinking water in learning. This is following the opinion that the fulfillment of student body fluid needs leads to optimal learning concentration (Watson \& Kelso, 2014).

The formation of the experimental group- 1 class students was carried out based on the top-down group and the right-left brain group, while the experimental-2 class was only formed according to the top-down group. Based on researchers' observations, students in the experimental-1 class interact in 
project planning and are more active when working on projects, giving rise to the same understanding between students in the group. This is consistent with the statement that the brain is a social brain, namely the principle of the brain, in terms of being happy with activities that require interaction in groups whose brain dominance is heterogeneous (Frith, 2007). Interaction and communication in the group also cause students to learn good learning outcomes as an opinion (Iksan et al., 2012) that to achieve success in learning also requires interaction and communication in groups.

In the experimental class-1, students who are dominant right brain will focus more on project design while students who are dominant left brain will focus more on the application of project concepts. This is consistent with the opinion (Corballis, 2014) students who are dominant left brain has the ability to analyze while students who are dominant right brain have the ability in creativity. Unlike the case with the experimental class- 2 students whose group formation is not based on brain dominance, students tend to be passive in interacting with their group peers. This is due to the possibility of one group of students of experimental class-2 having homogeneous brain dominance. For example, a group that is dominant in the right brain or dominant in the left brain. The dominant right brain group will continue to focus on project design and difficult to focus on the application of project concepts. Similarly, in the dominant left brain group, students will continue to focus on the application of concepts and experience difficulties in terms of project design.

The application of a brain gym is used to minimize student boredom due to a dense learning process and aims to prepare students to receive further learning (Sesmiarni, 2014). The application of a brain gym is made at the beginning of learning, and when students begin to not focus on learning. In a class that applies a brain gym, students are more enthusiastic about learning and more ready to accept the next learning. This is because movements in the brain gym can expedite blood flow and stretch the nerve muscles due to fatigue and stress as an opinion (Ramakrishnan \& Annakodi, 2013) that a brain gym can smoothen blood flow so students can concentrate more (Watson \& Kelso, 2014). The brain gym movement used is a different movement between the right hand and the left hand at the same time, which aims to balance the students' right and left brains. This is consistent with the opinion (Abduh \& Tahar, 2018), which states that the movement can be used as an exercise to balance students' right and left brains.

Similar to learning outcomes, the average N-Gain score of students' science process skill scores in the experimental class- 1 and experiment- 2 class also increased. This is evidenced by the average value of the N-Gain post-test score, which is better than the average value of the N-Gain score pre-test for students' science process skills in each class. Through PjBL learning that is applied in the experimental class- 1 and the experimental- 2 class, students have active learning experiences in the form of designing projects, working on projects, and presenting products as proposed by Larmer and Mergendoller (2015). Through these learning experiences, students can think and apply concepts directly so that they can meet aspects in the science process skills of students as the opinion expressed by Siwa et al. (2013) that every aspect of science process skills can be fulfilled and applied through PjBL. This is consistent with what was stated by Ozer and Ozkan (2012) that the application of PjBL could improve students' science process skills.

However, the increase in the average value of the N-Gain score of students' science process skills in the experimental class-1 is better than the average value of the $\mathrm{N}$-Gain score of the experimental class-2 (Table 2). One factor that distinguishes this is the application of brain-based learning. Experimental student-1 has a high concentration of learning. It was proven during the learning process, and the experimental class-1 students were not sleepy, actively asked questions, and argued. While the experimental class- 2 tends to be passive in the learning process, this indicates that learning applied to students in the experimental class-2 does not show the principle of pleasant learning, in accordance with the opinion (Hannah, 2013) that pleasant learning is learning that considers the condition of students in learning. Learning that pays attention to the condition of students causes students to have an optimal concentration of learning through paying attention to the condition of the student's brain as (Jensen, 2011) states that learning that pays attention to the condition of students can influence students concentration. The concentration of learning can be done in various ways, one of them by implementing a brain gym (Watson \& Kelso, 2014). 
Jurnal Inovasi Pendidikan IPA, 6 (1), 2020 - 97

Nur Lailatul Badriyah, Anik Anekawati, Lutfiana Fazat Azizah

\section{CONCLUSION}

Based on the results of research and discussion, it was concluded that there were differences in student achievement in the experimental class- 1 and the experimental-2 class. The average value of learning outcomes and science process skills of experimental class 1 students is better than in experimental class 2 .

\section{REFERENCES}

Abduh, B., \& Tahar, M. M. (2018). The effectiveness of brain gym and brain training intervention on working memory performance of student with learning disability. Journal of ICSAR, 2(2), 105111. https://doi.org/10.17977/um005v2i22018p105

Afriana, J., Permanasari, A., \& Fitriani, A. (2016). Penerapan project based learning terintegrasi STEM untuk meningkatkan literasi sains siswa ditinjau dari gender. Jurnal Inovasi Pendidikan IPA, 2(2), 202. https://doi.org/10.21831/jipi.v2i2.8561

Amin, M. S. (2018). Perbedaan struktur otak dan perilaku belajar antara pria dan wanita; eksplanasi dalam sudut pandang neuro sains dan filsafat. Jurnal Filsafat Indonesia, 1(1), 38. https://doi.org/10.23887/jfi.v1i1.13973

Amriyah, C. (2018). Optimalisasi cara berfikir siswa sekolah dasar pada mata pelajaran IPA melalui model pembelajaran kontruktivistik. Terampil: Jurnal Pendidikan Dan Pembelajaran Dasar, 5(1), 138. https://doi.org/10.24042/terampil.v5i1.2966

Biro Komunikasi dan Layanan Masyarakat Kementerian Pendidikan dan Kebudayaan. (2016). Peringkat dan capaian PISA Indonesia mengalami peningkatan. Kementerian Pendidikan Dan Kebudayaan Republik Indonesia. https://www.kemdikbud.go.id/main/blog/2016/12/peringkatdan-capaian-pisa-indonesia-mengalami-peningkatan

Buanasita, A., Yanto, A., \& Sulistyowati, I. (2015). Perbedaan tingkat konsumsi energi, lemak, cairan, dan status hidrasi mahasiswa obesitas dan non obesitas. Indonesian Journal of Human Nutrition, 2(1), 11-22. https://doi.org/10.21776/ub.ijhn.2015.002.01.2

Casey, B. (2012). STEM education: Preparing for the jobs of the future. https://www.jec.senate.gov/public/index.cfm/democrats/2012/4/stem-education-preparing-jobsof-the-future

Centre for the New Economy and Society. (2018). The future of jobs report. World Economic Forum. https://www.weforum.org/reports/the-future-of-jobs-report-2018

Corballis, M. C. (2014). Left brain, right brain: Facts and fantasies. PLoS Biology, 12(1), e1001767. https://doi.org/10.1371/journal.pbio.1001767

Creative Industries Federation. (2015). Industrial strategy for the creative industries. Creative Industries Federation (CIF). https://www.creativeindustriesfederation.com/sites/default/files/201705/Industrial Strategy.pdf

Darmadi, D. (2017). Pengembangan model dan metode pembelajaran dalam dinamika belajar siswa. Deepublish.

Ellis, R. J., \& Thayer, J. F. (2010). Music and autonomic nervous system (Dys)function. Music Perception, 27(4), 317-326. https://doi.org/10.1525/mp.2010.27.4.317

Fernandez-Cano, A. (2016). A methodological critique of the PISA evaluations. E-Journal of Educational Research, Assessment and Evaluation, 22(1), 1-16. https://doi.org/10.7203/relieve.22.1.8806

Frey, C. B., \& Osborne, M. A. (2017). The future of employment: How susceptible are jobs to computerisation? Technological Forecasting and Social Change, 114, 254-280. https://doi.org/10.1016/j.techfore.2016.08.019

Frith, C. D. (2007). The social brain? Philosophical Transactions of the Royal Society B: Biological Sciences, 362(1480), 671-678. https://doi.org/10.1098/rstb.2006.2003

Gorur, R. (2014). Towards a sociology of measurement in education policy. European Educational Research Journal, 13(1), 58-72. https://doi.org/10.2304/eerj.2014.13.1.58 
Hadinugrahaningsih, T., Rahmawati, Y., \& Ridwan, A. (2017). Developing 21st century skills in chemistry classrooms: Opportunities and challenges of STEAM integration. AIP Conference Proceedings 1868, 030008. https://doi.org/10.1063/1.4995107

Hannah, R. (2013). The effect of classroom environment on student learning [Western Michigan University]. https://scholarworks.wmich.edu/honors_theses/2375/

Henriksen, D. (2017). Creating STEAM with design thinking: Beyond STEM and arts integration. STEAM, 3(1), 1-11. https://doi.org/10.5642/steam.20170301.11

Holley, K. (2017). Interdisciplinary curriculum and learning in higher education. In Oxford Research Encyclopedia of Education. Oxford University Press. https://doi.org/10.1093/acrefore/9780190264093.013.138

Hudha, M. N., Triwahyuningtyas, D., Rafikayati, A., Fajaruddin, S., Maryani, I., Widiaty, I., Nandiyanto, A. B. D., Hamidah, I., \& Permanasari, A. (2019). How is STEM learning for children with special needs in Indonesia? Journal of Physics: Conference Series, 1402, 044104. https://doi.org/10.1088/1742-6596/1402/4/044104

Iksan, Z. H., Zakaria, E., Meerah, T. S. M., Osman, K., Lian, D. K. C., Mahmud, S. N. D., \& Krish, P. (2012). Communication skills among university students. Procedia - Social and Behavioral Sciences, 59, 71-76. https://doi.org/10.1016/j.sbspro.2012.09.247

Ismail, I., Permanasari, A., \& Setiawan, W. (2016). Efektivitas virtual lab berbasis STEM dalam meningkatkan literasi sains siswa dengan perbedaan gender. Jurnal Inovasi Pendidikan IPA, 2(2), 190. https://doi.org/10.21831/jipi.v2i2.8570

Jackson, J. (2016). Myths of active learning: Edgar Dale and the Cone of Experience. HAPS Educator, 20(2), 51-53. https://doi.org/10.21692/haps.2016.007

Jensen, E. (2011). Pemelajaran berbasis-otak paradigma pengajaran baru (Molan B (trans) (ed.)). PT. Indeks.

Jho, H., Hong, O., \& Song, J. (2016). An analysis of STEM/STEAM teacher education in Korea with a case study of two schools from a community of practice perspective. EURASIA Journal of $\begin{array}{lllll}\text { Mathematics, } \quad \text { Science } & \text { and }\end{array}$ https://doi.org/10.12973/eurasia.2016.1538a

Kaleci, D., \& Korkmaz, Ö. (2018). STEM education research: Content analysis. Universal Journal of Educational Research, 6(11), 2404-2412. https://doi.org/10.13189/ujer.2018.061102

Kim, H., \& Chae, D.-H. (2016). The development and application of a STEAM program based on traditional Korean culture. EURASIA Journal of Mathematics, Science and Technology Education, 12(7), 1925-1936. https://doi.org/10.12973/eurasia.2016.1539a

Kim, M. K., Lee, J. Y., Yang, H., Lee, J., Jang, J. N., \& Kim, S. J. (2019). Analysis of elementary school teachers' perceptions of mathematics-focused STEAM education in Korea. EURASIA Journal of Mathematics, Science and Technology Education, 15(9). https://doi.org/10.29333/ejmste/108482

Kor, L., \& Zakaria, S. F. (2019). Predicting student's STEM subject performance by using the Malay version of S-STEM. Universal Journal of Educational Research, 7(10), 2037-2044. https://doi.org/10.13189/ujer.2019.071001

Laksmi, P. K., Sujana, I. W., \& Abadi, I. B. G. S. (2014). Pengaruh model pembelajaran berbasis otak (brain based learning) berbantuan media teka-teki silang terhadap hasil belajar IPS siswa kelas V SD Gugus I Gusti Ngurah Jelantik. Jurnal Mimbar PGSD Universitas Pendidikan Ganesha Jurusan PGSD, 2(1). https://doi.org/10.23887/jjpgsd.v2i1.2055

Larmer, J., \& Mergendoller, J. (2015). Why we changed our model of the "8 essential elements of PBL." Buck Institute for " https://my.pblworks.org/resource/blog/why_we_changed_our_model_of_the_8_essential_elemen ts_of_pbl

Peraturan Menteri Pendidikan dan Kebudayaan Nomor 68 Tahun 2013 tentang Kerangka Dasar dan Struktur Kurikulum Sekolah Menengah Pertama/Madrasah Tsanawiyah, Pub. L. No. 68 (2013).

Miller, A. (2014). $P B L$ and STEAM education: $A$ natural fit. Edutopia. https://www.edutopia.org/blog/pbl-and-steam-natural-fit-andrew-miller 
National Service Center for Environmental Publications (NSCEP). (2013). Drinking water best management practices for schools and child care facilities with their own drinking water source. United States Environmental Protection Agency. https://nepis.epa.gov/Exe/ZyPURL.cgi?Dockey=P100HGM8.TXT

Organisation for Economic Co-Operation and Development. (2015). Pisa 2015 results in focus.

Organization for Economic Co-operation and Development. (2014). PISA 2012 results in focus: What 15-year-olds know and what they can do with what they know. OECD Publishing.

Ozer, D. Z., \& Ozkan, M. (2012). The effect of the project based learning on the science process skills of the prospective teachers of science. Journal of Turkish Science Education, 9(3), 119-130. http://www.tused.org/index.php/tused/article/view/443

Paparan Wakil Menteri Pendidikan Pendidikan dan Kebudayaan Republik Indonesia. (2014). Konsep dan implementasi Kurikulum 2013. Kementerian Pendidikan dan Kebudayaan.

Pfeiffer, C. F., \& Sabe, L. R. (2015). Music therapy and cognitive rehabilitation: Screening of music cognition in adult patients with right hemisphere stroke. Psychomusicology: Music, Mind, and Brain, 25(4), 392-403. https://doi.org/10.1037/pmu0000123

Psycharis, S. (2018). STEAM in education: A literature review on the role of computational thinking, engineering epistemology and computational science. Computational STEAM pedagogy (CSP). Scientific Culture, 4(2), 51-72. https://doi.org/10.5281/zenodo.1214565

Purwaningsih, N. W. A., Werdhiana, I. K., \& Syamsu, S. (2015). Pengaruh pendekatan pembelajaran berbasis otak terhadap pemahaman konsep kalor siswa kelas VII SMP Negeri 20 Palu. Jurnal Pendidikan Fisika http://jurnal.untad.ac.id/jurnal/index.php/EPFT/article/view/5114 Tadulako,

$3(2)$.

Quiles-Moukaddem, M., \& Hernandez, T. (2011). Brain-compatible teaching strategies. 12th Annual ISNA Educational Forum 2011 Workshop Paper. https://isna.net/wpcontent/uploads/2016/10/brain_based_learning_-_maribelmoukaddem.pdf

Ramakrishnan, J., \& Annakodi, R. (2013). Brain based learning strategies. International Journal of Innovative Research \& Studies, 2(5), 235-242.

Roberts, A. (2012). A justification for STEM education. TECHNOLOGY AND ENGINEERING TEACHERe. https://www.iteea.org/File.aspx?id=86478\&v=5409fe8e

Sani, R. A. (2014). Pembelajaran saintifik untuk implementasi Kurikulum 2013. Bumi Aksara.

Sani, R. A. (2015). Inovasi pembelajaran. PT Bumi Aksara.

Sazati, D. U. Z. (2015). Pengaruh penerapan group investigation berbantu teka-teki silang pada materi ekosistem terhadap keterampilan berpikir kritis siswa SMP [Universitas Negeri Semarang]. https://lib.unnes.ac.id/28797/1/4001411020.pdf

Sesmiarni, Z. (2014). Model pembelajaran ramah otak dalam implementasi Kurikulum 2013. Aura Publishing.

She, H. C., Stacey, K., \& Schmidt, W. H. (2018). Science and mathematics literacy: PISA for better school education. International Journal of Science and Mathematics Education, 16(S1), 1-5. https://doi.org/10.1007/s10763-018-9911-1

Siwa, I., Muderawan, I. W., \& Tika, I. N. (2013). Pengaruh pembelajaran berbasis proyek dalam pembelajaran kimia terhadap keterampilan proses sains ditinjau dari gaya kognitif siswa. Jurnal Pendidikan Dan Pembelajaran IPA Indonesia, 3(2). https://ejournalpasca.undiksha.ac.id/index.php/jurnal_ipa/article/view/794

Sjøberg, S. (2015). PISA and global educational governance - A critique of the project, its uses and implications. EURASIA Journal of Mathematics, Science and Technology Education, 11(1), 111127. https://doi.org/10.12973/eurasia.2015.1310a

Spoelstra, H., Rosmalen, P. Van, \& Sloep, P. (2014). Toward project-based learning and team formation in open learning environments. Journal of Universal Computer Science, 20(1). https://doi.org/10.3217/jucs-020-01-0057

Sumardi. (2014). Perbandingan kinerja otak kiri dan otak kanan dalam perkuliahan mahasiswa Jurusan 
Pendidikan Fisika Fakultas Tarbiyah dan Keguruan UIN Alauddin Makassar [Universitas Islam Negeri Alauddin Makassar]. http://repositori.uin-alauddin.ac.id/1793/

Susetyarini, R. E., Permana, T. I., Gunarta, G., Setyawan, D., Latifa, R., \& Zaenab, S. (2019). Motivasi dan tanggung jawab siswa dalam pembelajaran berbasis proyek, sebuah penelitian tindakan kelas. Jurnal Inovasi Pendidikan IPA, 5(1), 1-9. https://doi.org/10.21831/jipi.v5i1.22293

Takebayashi, T., \& Kumano, Y. (2018). Importance of development of STEM education for petrology and mineralogy. Jurnal Inovasi Pendidikan IPA, 4(1), 98-103. https://doi.org/10.21831/jipi.v4i1.18525

Watson, A., \& Kelso, G. L. (2014). The effect of brain gym on academic engagement for children with developmental disabilities. International Journal of Special Education, 29(2), 1-9.

Watthananon, J. (2018). A framework of learning achievement by STEAM education for system analysis and design in case study RMUTT. Asia-Pacific Journal of Science and Technology, 23(2), 1-8. https://doi.org/10.14456//kkurj.2018.1

Zubaidah, S., Mahanal, S., Yuliati, L., Dasna, I. W., Pangestuti, A. A., Puspitasari, D. R., Mahfudhillah, H. T., Robitah, A., Kurniawati, Z. L., Rosyida, F., \& Sholihah, M. (2017). Buku guru ilmu pengetahuan alam kelas VIII SMP/MTs. Kementerian Pendidikan dan Kebudayaan Republik Indonesia.

Zulkaida, A., Dewi, M. P., \& Prabowo, H. (2005). Metode mengajar dengan menstimulasi otak kiri dan otak kanan. Seminar Nasional PESAT, 96-103. http://repository.gunadarma.ac.id/925/ 